\title{
Challenges Ahead: Mitigating Air Transport Carbon Emissions
}

\author{
Miomir M. Jovanovic*, Bojan R. Vracarevic \\ University of Belgrade, Faculty of Geography, Belgrade, Serbia
}

Received: 19 February 2016

Accepted: 16 April 2016

\begin{abstract}
In this paper we confront widely accepted global climate stabilization goals ( $70 \%$ reduction of $\mathrm{CO}_{2}$ emissions) with the International Civil Aviation Organization's (ICAO) forecasts of future commercial aviation growth, in order to explore the real possibilities of realizing these climate stabilization goals. By using ICAO forecasts, we clearly show that, instead of the proclaimed $70 \%$ reduction of $\mathrm{CO}_{2}$ emissions, air transport's $\mathrm{CO}_{2}$ emissions are going to rise five-fold (4.9 times) in the 2005-40 period. But even if a $70 \%$ increase of aviation's energy efficiency and reduction of $\mathrm{CO}_{2}$ emissions could be somehow (miraculously) achieved, $\mathrm{CO}_{2}$ emissions of air transport would be higher by $50 \%$ in 2040 (than in 2005), due to the sudden increase in the volume of air-transport tourist trips. So, if the aim is to achieve ambitious energy consumption and GHG reduction for air transport within the next few decades, policies should aim at reducing total consumption, which means reducing VKT - not just vehicle-specific consumption. Due to the extremely high growth rates in the volume of air traffic, it is highly unlikely that technical progress of engines will be sufficient to reduce overall emissions or even keep them at today's levels. Hence, the policy focus should shift to more rigorous and efficient implementation of market-driven instruments, which, apart from creating incentives to develop and use low-emission technologies, can also reduce the demand for travel.
\end{abstract}

Keywords: air transport, $\mathrm{CO}_{2}$ emissions, radiative forcing, energy efficiency

\section{Introduction}

The Intergovernmental Panel on Climate Change [1] has declared that "warming of the climate system is unequivocal" and concluded that most of the observed increase in global average temperature since the mid-20th century is the result of human activities that are increasing greenhouse gas $(\mathrm{GHG})$ concentrations in the atmosphere.

The IPCC [1] further projected that the pace of climate change is going to accelerate with continued GHG emissions, and that even if atmospheric concentrations of

*e-mail: miomir.m.jovanovic@gmail.com
GHGs were stabilized at current levels, the Earth would continue to warm as a result of past GHG emissions and feedbacks in the global climate system [2].

The IPCC [1] suggests that even if $\mathrm{CO}_{2}$ emissions decline by $85 \%$ (of 2000 emissions) by 2050 , average global warming is likely to remain between $2.0^{\circ} \mathrm{C}$ and $2.4^{\circ} \mathrm{C}$ by the end of the century [2].

Hence, global atmospheric concentrations of carbon dioxide $\left(\mathrm{CO}_{2}\right)$ should be kept below 450 ppmv. In order to achieve this, a reduction of GHG emissions by about $80 \%$ is required by 2050 for developed economies, while at the same time room for development for developing countries is created. 
The contribution of aviation to climate change, with its global share of $3-5 \%$ of $\mathrm{CO}_{2}$ emissions, is often regarded as relatively small. However, this ignores the current and expected growth in air traffic, as well as its sociocultural drivers. Aviation is a rapidly growing sector [3-4]. In a carbon-constrained world with the ambition to reduce absolute levels of greenhouse gas emissions and limited options to technically achieve these, the growth in air traveler numbers thus indicates an emerging conflict [5].

Although presently a relatively small overall contributor to climate change, aviation is nevertheless an important polluter for several reasons. Firstly, the rapid growth of air transport - which is projected to continue - means that the industry will contribute increasingly to climate change in the future. Secondly, climate models indicate that the actual climate effects of aviation could be several times greater than the effects of aviation-derived $\mathrm{CO}_{2}$ alone. This enhanced impact occurs because aircraft create other greenhouse gases in addition to $\mathrm{CO}_{2}$; because aircraft emissions are injected directly into a climatically sensitive region of the atmosphere near the tropopause; and because other consequences of air transport (such as the formation of contrails and enhanced cirrus cloudiness) are themselves responsible for radiative impacts on climate. The effects of contrails and enhanced cirrus cloudiness caused by aircraft at cruise levels remain an important source of uncertainty in global climate modelling.

The share of tourism aviation of all aviation $\mathrm{CO}_{2}$ emissions is $73 \%$ (the remaining $27 \%$ originate from military and freight aviation) [6]. Assuming that emissions should be reduced on an equal basis for each sector, the tourism aviation sector faces substantial reduction demands while currently being characterized by rapid growth of emissions.

Climate change is to a considerable extent addressed by modelling and scenario building techniques. While forecasting techniques consists of gathering information about present conditions and then extrapolating them according to expectations and possible opportunities, in backcasting it is almost opposite, as our goal (where we want to be in the future) is used as a starting point and present conditions are adjusted according to the target we want to achieve.

Dubois et al. [7] give an excellent overview of different results obtained by using these techniques. With regard to transport, trend extrapolations or "business as usual" scenarios point to rapid growth in emissions over the next 30 years. Consequently, climate stabilization objectives increase the need for backcasting techniques and normative scenarios to identify pathways that could lead to emission reductions.

Moreover, the time horizon involved (50-100 years) means that adaptive models that can capture changes in critical parameters must be built. Finally, ambitious emission reduction targets - both proposed by IPCC [1] as well as adopted by governments - imply the need not only to consider quantitative changes relatively easily integrated in models, but also to explore the diversity of qualitative socio-cultural factors that shape, together with economic factors, current and future tourism demand.

In this respect, two main cultures/kind of (future) studies have emerged: a) the US school (mainly quantitative) and b) the French school (qualitative). The best way forward is to integrate both, which is a methodological challenge.

Finally, according to Dubois et al. [7] only a few longterm transport/tourism and climate change scenarios exist, none of them considering climate stabilization. Existing works either: a) assess crudely key driving forces behind emissions reductions (technological progress, behavioral change), or b) use quantitative forecasting techniques, based on more or less fixed relationships (for instance between GDP and mobility).

In this paper we are going to confront widely accepted global climate stabilization goals, with the most reliable/ realistic up-to-date ICAO forecasts of future commercial aviation growth, in order to explore the real possibilities of realization of these climate stabilization goals, and to analyze the main drivers of this rapid aviation growth.

\section{Materials and Methods}

\section{Calculating Emissions and Radiative Forcing of Air Transport}

Air transport emissions of $\mathrm{CO}_{2}$ are directly related to the amount of fuel: every $\mathrm{kg}$ of fuel (kerosene; Jet A) used will lead to $3.155 \mathrm{~kg}$ of $\mathrm{CO}_{2}$ emitted to the atmosphere [8]. Actually, the climate effect of $\mathrm{CO}_{2}$ emissions from aviation results in a change of balance between incoming solar radiation and outgoing terrestrial radiation (a radiative forcing) of $25.3 \mathrm{mWm}^{-2}$. The most common method to calculate emissions uses the product of the amount of work performed (e.g., seat kilometres) and the average emissions per unit of work (the emission factor):

$$
\mathrm{E}_{\mathrm{x}}=\beta_{\mathrm{x}} X \mathrm{~V}
$$

However, traffic volume (V) and emission factor $\left(\beta_{x}\right)$ may be expressed using seat $\mathrm{km}$ or passenger $\mathrm{km}$, so one value may need to be converted. Aircraft are generally most efficient at medium distances, as at short distances the energy-intensive takeoff and climb sections comprise a relatively large share, while at long-haul distances the amount of fuel to be carried at takeoff and climb-out requires extra energy. This impact of distance flown on emissions per $\mathrm{km}$ can be taken into account by a correction factor (Table 1).

However, aviation's effect on global warming is not only expressed through $\mathrm{CO}_{2}$ emissions, but also through the level of RF (radiative forcing).

Aviation has the following non- $\mathrm{CO}_{2}$ impacts on the climate $\left(\mathrm{mWm}^{-2}\right.$ in 2000 :

a) $\mathrm{NO}_{x}$ induces the forming of $\mathrm{O}_{3}$, which has a short-lived warming effect $\left(21.9 \mathrm{mWm}^{-2}\right)$. 
Table 1. Relationship between emission factor and (mediumrange, medium-size) aircraft distance flown [9].

\begin{tabular}{|c|c|}
\hline Distance flown $(\mathrm{km})$ & Distance correction factor \\
\hline$<500$ & 1.86 \\
\hline 750 & 1.39 \\
\hline 1,250 & 1.18 \\
\hline 1,750 & 1.09 \\
\hline $2,000-5,000$ & 1.00 \\
\hline$>5,000$ & 1.05 \\
\hline
\end{tabular}

b) $\mathrm{NO}_{x}$ also induces a reduction of $\mathrm{CH}_{4}$, thus creating a longer-lived cooling effect $\left(-10.4 \mathrm{mWm}^{-2}\right)$.

c) Direct short-lived $\mathrm{H}_{2} \mathrm{O}$ emissions $\left(2.0 \mathrm{mWm}^{-2}\right)$.

d) Direct short-lived sulphate emissions $\left(-3.5 \mathrm{mWm}^{-2}\right)$.

e) Direct short-lived soot $\left(2.5 \mathrm{mWm}^{-2}\right)$.

f) Very short-lived contrails $\left(10.0 \mathrm{mWm}^{-2}\right)$.

g) Very short-lived contrail-induced cirrus (best estimate: $30 \mathrm{mWm}^{-2}$, upper limit $80 \mathrm{mWm}^{-2}$ ).

These impacts on radiative forcing (excluding $\mathrm{CO}_{2}$ and cirrus) amount to $22.5 \mathrm{mWm}^{-2}$.

To add $\mathrm{CO}_{2}$ and non- $\mathrm{CO}_{2}$ impacts, differences in their characteristics must be considered. For most non-aviation emissions, global warming potential (GWP) can be used to compare the impact of $1 \mathrm{~kg}$ of a gas with that of $1 \mathrm{~kg}$ of $\mathrm{CO}_{2}$. However, this measurement is less suitable for the non- $\mathrm{CO}_{2}$ impacts of aviation as they are dependent on the altitude and location of emissions. Many authors within transport scenario studies incorporate the additional warming from non- $\mathrm{CO}_{2}$ impacts using a constant factor of 2.7 , often imprecisely referred to as an "equivalence factor" [9].

We are now going to confront widely accepted global climate stabilization goals with the ICAO's forecasts [10] of future commercial aviation growth (until 2040), to explore the real possibilities of realization of these climate stabilization goals.

As a widely accepted global climate stabilization goal we use the IPCC [1] suggestion that global $\mathrm{CO}_{2}$ emissions should decline by $85 \%$ of 2000 emissions by 2050 , in order to keep average global warming under control by the end of the century (between $2.0^{\circ} \mathrm{C}$ and $2.4^{\circ} \mathrm{C}$ ).

We use ICAO traffic and fleet forecasts for future commercial aviation growth. The ICAO traffic and fleet forecasts have been developed by the Forecasting and Economic Analysis Support Group (FESG) of the ICAO Committee on Aviation Environmental Protection (CAEP) and form the basis of various analyses conducted within CAEP. The CAEP forecast is based on forecasts, inputs, and models provided by member states, observer organizations (i.e., aircraft and engine manufacturers, air navigation service providers, aviation safety agencies, etc.) and the ICAO Secretariat. The forecast covers a 30 -year time horizon. Three growth scenarios have been developed: most likely, high, and low. In this paper we use the "most likely" forecast.
Table 2. Approximation of European tourism air transport $\mathrm{CO}_{2}$ emissions for different destinations (different trip lengths) for 2005 [6].

\begin{tabular}{|c|c|c|}
\hline Destination & $\begin{array}{c}\text { Aircraft pkm } \\
\text { (avg. return) }\end{array}$ & $\begin{array}{c}\text { Emission of } \mathrm{CO}_{2} \\
(\mathrm{~kg} / \mathrm{pkm})\end{array}$ \\
\hline Domestic & 1,900 & 0.138 \\
\hline Europe & 2,500 & 0.125 \\
\hline Near/Middle East & 3,900 & 0.125 \\
\hline Rest of the world & 16,000 & 0.124 \\
\hline
\end{tabular}

\section{$\mathrm{CO}_{2}$ Emissions from Air Transportation}

This item did not require collection by itself, as $\mathrm{CO}_{2}$ emissions are linked to energy consumption, which is already available through the original data set. The conversion factor from joules of energy consumed to grams of $\mathrm{CO}_{2}$ emitted is dependent on the type of fuel involved in the energy generation and flight length.

Table 2 shows an assessment based on data by UNWTO, ICAO, and IATA of the number of international tourist trips within and between regions, and the related travel distances and emissions.

The data about average per capita emissions of $\mathrm{CO}_{2}$ from air passenger transport for 2013 have been calculated from the detailed EUROSTAT surveys/data for $23 \mathrm{EU}$ countries on tourist trips and air transport through standard grams of $\mathrm{CO}_{2}$ per $\mathrm{MJ}$ conversion factors.

Since carbon emissions of an aircraft depend on distance travelled, air trips have been divided into four categories (domestic, Europe, Near/Middle East, rest of the world) and corresponding carbon emissions $(0.138 \mathrm{~kg} /$ pkm, $0.125 \mathrm{~kg} / \mathrm{pkm}, 0.125 \mathrm{~kg} / \mathrm{pkm}, 0.124 \mathrm{~kg} / \mathrm{pkm}$ ) used for our estimates/analysis.

The data about average GDP per capita for 2013 for 23 EU countries also have been calculated from the detailed EUROSTAT surveys/data.

We used statistical SPSS software to calculate Pearson's correlation coefficient.

\section{Results and Discussion}

\section{Different Scenarios for Reducing Air Transport $\mathrm{CO}_{2}$ Emissions}

According to the U.S. National Academy of Sciences, energy consumption and $\mathrm{CO}_{2}$ emissions in transport can be significantly reduced only by:

a) Increasing energy efficiency of different transport modes.

b) Focusing on those transport modes that consume less energy and have lower $\mathrm{CO}_{2}$ emissions.

c) Reducing the transport volume [11].

a) Air transport prospects for further increasing fuel efficiency are relatively low because the technology of jet aircraft has already more or less matured. Alternative 
fuels will not be introduced on a large scale within the next three to five decades, unless strong government incentives are given.

Although some researchers (like Schafer and Victor [12]) state that "Since 1960, fuel consumption per pkm of new aircraft decreased by $30 \%$; and further reductions in the order of $70 \%$ are possible by 2050 ," there is growing evidence that this is an overly optimistic approach. After careful analysis of historical and future trends of fuel efficiency of commercial aircraft, Peeters et al. [13], for example, conclude that "the common practice of defining future cuts in energy consumption in terms of a constant annual percentage reduction is not very true to reality ..." and that ... "many studies on predicted future gains are rather optimistic."

Annual fuel efficiency improvements in the aviation sector through technology and fleet renewal have declined and are estimated to decrease further, and when combined with growth in demand, net growth in fuel use is consequently estimated to increase over the next two decades [14].

The production of biofuels in commercial-scale volumes after 2030 seems to be one option to achieve absolute emission reductions [15], but are highly problematic at the production scale required. Assuming that existing technical limitations to using biofuels as a replacement in existing fuel delivery and engine systems can be resolved, existing biofuels have lower- volumetricenergy density (MJ/L) than Jet A fuel [16]. Hence, aircraft using biofuels would have a reduced range. Also, a huge barrier to the substitution of biofuels in jet aircraft is the massive land area required to produce sufficient quantities to replace a significant portion of fuel needs. Replacing conventional fuels with advanced biofuels like Jatropha consequently translates into area requirements of more than 1 million $\mathrm{km}^{2}$, which corresponds roughly to the size of Germany, France, the Netherlands, and Belgium combined. Algae might be another alternative, but expectations on algae exceed their potential, with many technical and biological problems remaining unsolved [17]. Nevertheless, there is still ongoing discussion regarding the capacity of biofuels to replace conventional jet fuel $[15,18]$ and vigorous debate over food security versus energy crops [19].

It should also be noted that air fuel made from biomass does not reduce the emissions of $\mathrm{NO}_{x}$ and $\mathrm{H}_{2} \mathrm{O}$, which together make up nearly half the total climate impact from aviation.

Alternative fuels will not be introduced on a large scale within the next three to five decades unless strong government incentives are given.

b) Considering transport modes that consume less energy and have lower $\mathrm{CO}_{2}$ emissions, a less risky strategy might be, as Akerman [20] proposes, to opt for the slower aircraft configuration of an advanced turboprop aircraft cruising at between 640 and $700 \mathrm{kph}$. But although this aircraft configuration entails a further $25 \%$ cut of $\mathrm{CO}_{2}$ emissions, it dangerously enters the domain of the European high-speed (mid-range) rail network and is not especially promising/suitable for longrange trips.

Obviously, the realization of absolute emission reductions as outlined by IATA are thus highly uncertain [2].

c) Considering reduction of the transport volume, of fundamental importance to the future of tourism's transport contribution to climate change are two strong growth trends that characterize the sector.

First, there is a rapidly growing number of people participating in both domestic and international tourism and air transport [2].

Second, travelers participate in more frequent and more distant trips [6], and stay over shorter periods of time. An increasing number of tourists is being directed toward faraway, exotic destinations, until recently reserved only for a wealthy minority. Travelling is now more frequent, but shorter (in terms of time required/consumed), and oriented toward increasingly distant destinations.

Such a sudden increase in the volume of tourist trips hypermobility - has been made possible, in the first place, by the expansion of low-cost airlines, increased living standards, educational levels, and additional free time. Low-cost airlines are now carrying some 306 million passengers per year in the European Union alone [21]. Hypermobility is today a recognizable behavioral norm, while travel that uses every bit of free time - a routine condition. The vast majority of air travelers, of course, currently originate from developed countries, even though there are some recent trends, particularly in China and India, that show rapid growth in air travel [22]. So, in developed countries tourism has undergone essential changes during the past decade [8].

Consequently, reduction of the transport volume of aviation and its climate impacts can only be properly understood, and responded to fully, if the drivers of aviation growth are themselves properly understood.

A comparatively large share of passenger flight kilometres, and thus emissions, corresponds to air travel between the various regions (Europe, the Americas, Asia and the Pacific, the Middle East, Africa). UNWTO has developed a matrix allowing for a breakdown of trip volumes by regions of origin and (sub)regions of destination. Based on this UNWTO matrix, an assessment has been made of the flows between high-income and developing countries, which shows that high income countries have the lion's share of global tourism air transport and $\mathrm{CO}_{2}$ emissions - more than $72 \%$ of all trips and $72 \%$ of $\mathrm{CO}_{2}$ emissions - while developing countries' share is only $28 \%$ of air transport trip volume and $\mathrm{CO}_{2}$ emissions [6]. Also, high-income countries have dramatically higher $\mathrm{CO}_{2}$ emissions $(137.111 \mathrm{~kg} /$ per capita) in the tourism air transport in comparison to developing countries, that have only negligible $\mathrm{CO}_{2}$ emissions (10.709 kg/per capita) [6]. (According to the World Bank Country Classification, "high income" countries are those with a gross domestic product (GDP) of $\$ 12,736$ per capita or more, while developing countries have less than $\$ 12,736$ per capita [23]). 
Table 3. GDP per capita and air transport $\mathrm{CO}_{2}$ emissions per capita for selected EU countries in 2013.

\begin{tabular}{|c|c|c|c|c|c|c|}
\hline & \multirow{2}{*}{$\begin{array}{l}\text { GDP per capita } \\
(€)\end{array}$} & \multirow{2}{*}{$\begin{array}{l}\text { Emissions of } \mathrm{CO}_{2} \\
\text { per capita (in } \mathrm{kg} \text { ) }\end{array}$} & \multicolumn{4}{|c|}{ Emissions of $\mathrm{CO}_{2}$ per capita share (in \%) } \\
\hline & & & Domestic & Europe & Middle East & Rest of the world \\
\hline 23 EU countries & 22,787 & 177.88 & 7.35 & 33.16 & 2.61 & 56.88 \\
\hline Belgium & 35,400 & 230.44 & 0 & 38.73 & 1.69 & 59.58 \\
\hline Bulgaria & 5,800 & 14.25 & 0 & 36.26 & 2.79 & 60.95 \\
\hline Czech Republic & 14,900 & 109.68 & 0 & 36.48 & 3.07 & 60.45 \\
\hline Denmark & 45,500 & 358.57 & 5.19 & 56.67 & 1.9 & 36.24 \\
\hline Germany & 35,000 & 285.45 & 5.69 & 31.58 & 2.77 & 59.95 \\
\hline Estonia & 14,400 & 192.63 & 0 & 53.85 & 0.01 & 46.13 \\
\hline Ireland & 39,000 & 503.73 & 0.34 & 59.04 & 2.16 & 38.46 \\
\hline Greece & 16,500 & 21.73 & 24.6 & 37.15 & 3.04 & 35.16 \\
\hline Spain & 22,100 & 93.54 & 39.6 & 32.62 & 0.78 & 26.99 \\
\hline France & 32,100 & 179.70 & 12 & 19.05 & 1.86 & 67.04 \\
\hline Croatia & 10,200 & 52.25 & 6.59 & 68.74 & 1.99 & 22.67 \\
\hline Italy & 26,500 & 67.55 & 20.6 & 34.22 & 2.73 & 42.45 \\
\hline Latvia & 11,300 & 138.96 & 0 & 43.5 & 0.76 & 55.75 \\
\hline Lithuania & 11,800 & 119.22 & 0 & 66.86 & 0.36 & 32.78 \\
\hline Hungary & 10,200 & 40.12 & 0 & 71.75 & 4.84 & 23.41 \\
\hline Netherlands & 38,700 & 338.00 & 0 & 27.61 & 1.66 & 70.73 \\
\hline Austria & 38,100 & 277.83 & 0 & 46.81 & 3.71 & 49.48 \\
\hline Poland & 10,200 & 46.56 & 0 & 58.82 & 2.27 & 38.91 \\
\hline Portugal & 16,300 & 47.79 & 11.7 & 42.61 & 0.55 & 45.18 \\
\hline Romania & 7,200 & 5.87 & 19.4 & 66.72 & 4.04 & 9.875 \\
\hline Slovakia & 13,600 & 44.73 & 0 & 63.79 & 0.73 & 35.48 \\
\hline Finland & 37,400 & 472.05 & 7.32 & 38.37 & 0.48 & 53.83 \\
\hline United Kingdom & 31,900 & 450.55 & 3.01 & 30.69 & 3.37 & 62.93 \\
\hline
\end{tabular}

Estimated according to [6, 24].

Although calculating the contributions of global transport to climate change has so far focused mainly on international air transport due to the limited availability of comprehensive data on domestic demand (see UNWTOUNEP 2008), there are now fairly reliable data about the EU provided by EUROSTAT [24]. Table 3 shows GDP per capita (expressed in euros) and air transport $\mathrm{CO}_{2}$ emissions per capita (in $\mathrm{kg}$ ) for our sample of $23 \mathrm{EU}$ countries, while Fig. 1 clearly shows the very strong correlation $(0.84)$ between GDP per capita and air transport $\mathrm{CO}_{2}$ emissions per capita.

The very high value of Pearson's correlation coefficient (value of correlation coefficient is 0.84 ; correlation is significant at the 0.01 level) for GDP per capita and air transport $\mathrm{CO}_{2}$ emissions per capita (for our sample of 23 EU countries) convincingly illustrates the importance of increasing living standards for quickly rising air transport mobility and total $\mathrm{CO}_{2}$ emissions in air transport (Fig. 1).

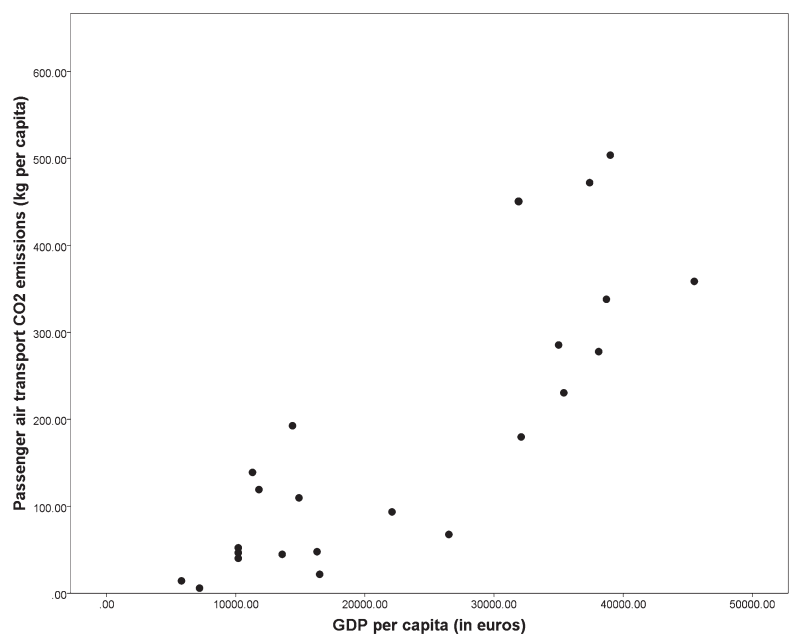

Fig. 1. Correlation between GDP per capita and passenger air transport $\mathrm{CO}_{2}$ emissions per capita. 
Table 4. EU aviation/air company passengers 2005-15 (in millions).

\begin{tabular}{|c|c|c|c|c|c|c|c|c|c|c|c|}
\hline Year & $\mathbf{2 0 0 5}$ & $\mathbf{2 0 0 6}$ & $\mathbf{2 0 0 7}$ & $\mathbf{2 0 0 8}$ & $\mathbf{2 0 0 9}$ & $\mathbf{2 0 1 0}$ & $\mathbf{2 0 1 1}$ & $\mathbf{2 0 1 2}$ & $\mathbf{2 0 1 3}$ & $\mathbf{2 0 1 4}$ & $\mathbf{2 0 1 5}$ \\
\hline Low-cost companies & 58.6 & 106 & 120.7 & 149.5 & 162.5 & 172.4 & 188.8 & 193.7 & 216 & 236.3 & 306.2 \\
\hline EU Aviation & 671.4 & 712.8 & 788.9 & 18.71 & 752.6 & 778.3 & 822.8 & 828.2 & 842.2 & 877.0 & 965.3 \\
\hline $\begin{array}{c}\text { Share of low-cost com. } \\
(\%)\end{array}$ & 8.70 & 14.9 & 15.3 & 18.71 & 21.59 & 22.15 & 22.95 & 23.39 & 25.65 & 26.94 & 31.7 \\
\hline
\end{tabular}

Estimated according to [21, 24].

Our results/findings are in sharp contrast with the EKC hypothesis while (at the same time) being completely in line with the results of Seetaram et al. [25].

According to the EKC hypothesis, the relationship between the rate of economic development (expressed in terms of income per capita) and (various indicators of) environmental degradation have the turning point at approximately U.S. $\$ 5,000$ per capita, after which pollution abruptly decreases. According to the EKC hypothesis, higher levels of economic development, therefore, inevitably lead toward increasingly better protection of the environment. But insisting solely on encouraging economic growth leads to complete neglect of the impact that increased volume growth of air transport has on $\mathrm{CO}_{2}$ emissions [26].

For example, a study by Seetaram et al. [25] points out that a $10 \%$ increase in income will cause air transport (and consequently $\mathrm{CO}_{2}$ emissions) to rise by $23.9 \%$ in the long run. Their results clearly show that an increase in income will lead to a greater-than-proportionate rise in air transport. This information is essential to policymakers in their assessment of the impacts of existing and potential new fiscal and monetary policies regarding air transport consumption. Such information is also crucial for developing strategies and plans for the air transport industry and fundamental to forecasting exercises and for calibrating economic models that appraise the likely consequences of demand and supply shocks on the economic contribution of transport.

Also, it must be pointed out that the lion's share of EU air transport growth has lately been dedicated to low-cost companies. While from 2005 to 2015 the total number of air transport passengers grew from 670 to 965 million (295 mil. growth), at the same time low-cost companies grew from 59 to 306 mil. passengers carried (247 mil. increase). Hence, low-cost companies' share in the total number of EU air transport passengers carried rose from $8.7 \%$ to $32 \%$ (Table 4 ).

The main reason for such powerful growth by lowcost companies lies in their extremely low prices, which are, at the same time, the main cause of the EU air transport's quickly growing $\mathrm{CO}_{2}$ emissions in 2005-15. Thus our results are important since policymakers are highly influenced by climate change contrarians and aviation lobbies, who are all engaged in considerable efforts to implement an understanding that all mobility is good, while environmental problems can be resolved largely either through: a) technological innovation or b) economic growth (which both inevitably lead to rapid decarbonization). Consequently, it is obvious that technological innovation alone is unlikely to achieve climate targets unless the drivers of aviation growth are themselves properly understood.

Akerman points out that the share of greenhouse emissions attributable to air transport may increase rapidly if its volume growth is not radically curbed [20]. But this seems to be an almost impossible task, complicated by the strong sustained growth of demand for air transport; the importance of the air transport industry in driving economic growth in other sectors; the strong links between aviation growth, tourism growth, and processes of globalization; the broad popularity of air travel; and the fact that the industry is international in its scope, regulated by myriad bilateral air service agreements [27].

The magnitude and speed of growth in aircraft passenger kilometers, its energy consumption, and $\mathrm{CO}_{2}$ emissions for 2005-40 are shown in Table 5.

Table 5. Aircraft passenger kilometers, energy consumption, and $\mathrm{CO}_{2}$ emissions for 2005-40.

\begin{tabular}{|c|c|c|c|c|c|}
\hline Year & $\mathbf{2 0 0 5}$ & $\mathbf{2 0 1 0}$ & $\mathbf{2 0 2 0}$ & $\mathbf{2 0 3 0}$ & $\mathbf{2 0 4 0}$ \\
\hline Aircraft pkm (in bill.) & 3,984 & 5,051 & 8,453 & 13,157 & 19,462 \\
\hline Energy consumption (MJ/pkm) & 2.0 & 2.0 & 2.0 & 2.0 & 2.0 \\
\hline Emission of $\mathrm{CO}_{2}(\mathrm{~kg} / \mathrm{pkm})$ & 0.129 & 0.129 & 0.129 & 0.129 & 0.129 \\
\hline Total Energy consumption (TJ) & 7,968 & 10,102 & 16,906 & 26,314 & 38,924 \\
\hline Total Emission of $\mathrm{CO}_{2}(\mathrm{t})$ & 513,936 & 651,579 & $1,090,437$ & $1,697,253$ & $2,510,598$ \\
\hline
\end{tabular}

Estimated according to $[6,10]$. 
By using ICAO's aircraft passenger kilometers forecasts for 2020-40 (Table 5), we clearly show that energy consumption and $\mathrm{CO}_{2}$ emissions of air transport are going to rise five-fold (4.9 times) in 2005-40 in a "business-as-usual" scenario. But even if the (already proclaimed, overly optimistic) $70 \%$ increase of aviation's energy efficiency and reduction of $\mathrm{CO}_{2}$ emissions could be somehow (miraculously) achieved, with such a sudden increase in the volume of air-transport tourist trips, $\mathrm{CO}_{2}$ emissions of air transport would be $50 \%$ higher in 2040 than in 2005.

Hence, the current climate policy for passenger transportation is insufficient to achieve significant emission reductions in line with global climate stabilization goals if its volume growth is not radically curbed.

Since even with $70 \%$ reduction of aviation's $\mathrm{CO}_{2}$ emissions, a five-fold rise of aviation volume translates into $50 \%$ total $\mathrm{CO}_{2}$ emissions increase, it is obvious that other climate policy instruments must be applied (apart from measures concentrated only on increasing energy efficiency).

Worldwide, the air transport sector's energy and $\mathrm{CO}_{2}$ trends are strongly linked to rising population and incomes. Another crucial aspect of the global air transport system is that the majority of the world's population does not have access to air transport (due to low incomes). As income in developing nations grows, air transport will grow even more rapidly. When these areas develop and respective population incomes rise, the prospects for vast expansion of air transport and an increase in fossil fuel use and GHG emissions will become very real. And these prospects are exacerbated by evidence that the most attractive form of transport for most people as their incomes rise is aviation, which is faster, more flexible, more convenient, more comfortable, and is viewed as a status symbol.

If the aim is to achieve ambitious energy consumption and GHG reduction for air transport within the next few decades, policies will have to be more determined. They should aim at reducing total consumption, which means reducing VKT - not just vehicle-specific consumption [26, 28-29].

Due to growth rates in the volume of traffic, it is unlikely that progress in engine technology will be sufficient to reduce overall emissions or even keep them at today's levels. For that reason, the focus is increasingly shifting to market-driven instruments, which, apart from creating incentives to develop and use low-emission technologies, can also reduce the demand for travel.

Joumard rightfully stresses that "only $40 \%$ of the effort required should focus on technology, while the remaining $60 \%$ should focus on managing demand for transport and the adoption of more sustainable modes of transport" [30].

To achieve emission reductions in transport in the EU, a wide range of market-based, command-and-control, and soft policy measures are theoretically available [31-32]. However, while there is ample research on the effects of specific measures within these three categories, there exists, in the words of Banister and Hickman [33], a major "implementation gap" defined as the way in which scientific knowledge is translated into policies.

Gossling et al. [34] developed an alternative concept for explaining why available policy measures are not being implemented, which they term "transport taboos." According to them, transport taboos are issues that constitute fundamental yet ignored cognitive and affective barriers to the implementation of significant (climate) policy in transportation. Taboos are different from barriers of implementation, because they exist on a fundamentally different level than structural, economic, technical, or behavioral barriers: they cannot be addressed politically without considerable danger to the powerful individuals or organizations, or the broader public or community [34]. Transport taboos exist, it is argued, because they constitute a risk to political decision makers, in the sense that their consideration would require transcending neoliberal forms of governance to initiate fundamental sociocultural change - in other words, it would be a process creating disorder.

For example, although transport accounts for $29.9 \%$ of $\mathrm{CO}_{2}$ emissions in the $\mathrm{EU}$ (in 2009; [35]) and significant continued growth in transport volumes is expected, indicating vast discrepancies between emission reduction objectives and business-as-usual developments, there is no evidence of a political acknowledgment that the sector's growth contradict mitigation objectives, and no systematic assessment of the effectiveness of various policy measures for reducing emissions.

The mismatch is particularly evident in aviation, where the International Air Transport Association (IATA) has presented a vision of "carbon-neutral growth" achievable in the "medium-term" future [36]. The organization outlines timelines in its "four-pillar strategy," acknowledging that the technology that will be necessary to achieve these goals is yet unknown, and referring to "revolutionary engine architectures" to be implemented after 2020 .

Table 6. European aircraft passenger kilometers, energy consumption and $\mathrm{CO}_{2}$ emissions for 2010 and forecast for 2040 .

\begin{tabular}{|c|c|c|}
\hline Year & $\mathbf{2 0 1 0}$ & $\mathbf{2 0 4 0}$ \\
\hline Aircraft pkm (in bill.) & 1,435 & 5,196 \\
\hline Energy consumption (MJ/pkm) & 2.0 & 2.0 \\
\hline Emission of $\mathrm{CO}_{2}(\mathrm{~kg} / \mathrm{pkm})$ & 0.129 & 0.129 \\
\hline Total Energy consumption (TJ) & 2,870 & 10,392 \\
\hline Total Emission of $\mathrm{CO}_{2}(\mathrm{t})$ & 185,115 & 670,284 \\
\hline $\begin{array}{c}\text { Share of Europe in Global } \mathrm{CO}_{2} \\
\text { emission (\%) }\end{array}$ & 28.4 & 26.7 \\
\hline $\begin{array}{c}\text { Share of Europe in World } \\
\text { Population (\%) }\end{array}$ & 10.6 & 7.9 \\
\hline $\begin{array}{c}\text { European } \mathrm{CO}_{2} \text { emission per capita } \\
\text { (kg) }\end{array}$ & 251.7 & 929.2 \\
\hline Global $\mathrm{CO}_{2}$ emission per capita $(\mathrm{kg})$ & 94.0 & 274.2 \\
\hline
\end{tabular}

Estimated according to $[6,10,37]$. 
Hence in Table 6 we gave air transport $\mathrm{CO}_{2}$ emissions a business-as-usual scenario for Europe for 2010-40. It convincingly shows that, if nothing changes, although the European share in global population is going to fall from 11 to $8 \%$, its very high share in the global $\mathrm{CO}_{2}$ emissions remains the same (27-28\%) due to its almost four-fold (3.7) rise of emissions per capita. Hence, total European air transport $\mathrm{CO}_{2}$ emissions are expected to grow from 185,115 to 670,284 tons in $2010-40$.

In order to avoid this huge $\mathrm{CO}_{2}$ emissions increase in the next few decades in regard to climate policy, three options for mitigation are distinguished, namely: global climate policies relying on economic instruments such as pricing, taxation, and carbon trading.

Most measures to reduce emissions in transport are market-based. Regarding aviation, the EU has sought to integrate the sector in carbon trading through an open European Union Emission Trading Scheme (EU ETS). The inclusion of aviation within the EU ETS is based on the "downstream emissions trading model" in which it is the aircraft operator who must cover the $\mathrm{CO}_{2}$ emissions generated by their units or engines [38]. This remains the only regional policy approach for the aviation sector worldwide [39]. According to the European Commission, inclusion of aviation in the ETS would achieve reductions of $183 \mathrm{Mt} \mathrm{CO}_{2}$, or the equivalent of a $46 \%$ reduction compared to a business-as-usual scenario. Despite all theoretical debates, the (rather disappointing) final result is that obligations placed on airlines are extremely low. Furthermore, if transport emissions were to be restricted and transport volumes continue to grow, the cheaper emissions reductions would soon be exhausted and abatement costs would then increase significantly [40]. Also, as the commission points out, the option of purchasing credits from within the EU ETS means that the sector will continue to grow, and emission reductions will be achieved in other sectors where costs are lower [41]. Analyses of the implications of cost increases under various ETS or climate policy scenarios all conclude that those currently planned will not significantly change travel flows [42] or reduce absolute emissions from the aviation sector [2, 41, 43-44]. In light of the low costs of purchasing emission allowances, the EU ETS is thus unlikely to have any de facto importance for airlines and growth in aeromobility, while flights to and from nonEuropean countries are not included at least until 2020 [45]. Vice versa, various forms of subsidies exist, which make flying cheaper in proportion with mobility levels.

Aviation is the most-energy-intense transport that is the least taxed and the most subsidized. It is exempted from VAT on international flights - a subsidy corresponding to a revenue shortfall of $\$ 10$ billion in the EU according to [35] and does not pay fuel taxes. Thus, this sector remains the only transport sector not to be taxed (domestic flights can be an exception), which results in competitive distortions with the more environmentally friendly transport modes.

In further contradiction with sustainable transport policy principles, scheduled and low-cost carriers continue to receive direct subsidies. Ryanair alone may have received subsidies of approximately $€ 800$ million in a single year, which contributed enormosly to the carrier's quickly attained financial success in the last decade, and whose number of passengers carried rapidly rose from 37.6 million to 94.3 million in 2006-15 [21].

Also, those travelling more frequently over long distances or in business/first class, are the most subsidized. Moreover, other subsidies are paid as governmental support to national airlines in times of crisis, or regional airports with year-on-year negative balance sheets. Obviously, there is a need to more fundamentally question policy structures and the entrapment of transport, dominated by neoliberal, technocentric, and ecological modernization values that make policy learning and the questioning of prevailing paradigms difficult.

In short, without overcoming transport taboos, significant sustainable transport policies on a broader scale are unlikely to emerge. The interrelationship between climate change and aviation is complex. As Gossling and Uphman [8] point out, aviation and its climate impacts can only be properly understood, and responded to fully, if the drivers of aviation growth are themselves properly understood. Rapid growth in air travel is a product of specific and powerful social, economic, cultural, technological, and commercial trends as well as a special, often preferential treatment, in politics. Intervention at any one of these levels alone will not suffice to bring air travel within climatic constraints in the short timescale required, though progress in any one aspect may help progress in the others.

\section{Conclusion}

In this paper we confronted widely accepted global climate stabilization goals $\left(70 \%\right.$ reduction of $\mathrm{CO}_{2}$ emissions), with the ICAO's forecasts of future commercial aviation growth, in order to explore the real possibilities of realizing these climate stabilization goals. By using ICAO forecasts, we clearly show that, instead of a proclaimed $70 \%$ reduction of $\mathrm{CO}_{2}$ emissions, energy consumption and $\mathrm{CO}_{2}$ emissions of air transport are going to rise fivefold (4.9 times) in the $2005-40$ period. Hence, even if a $70 \%$ increase of aviation's energy efficiency and reduction of $\mathrm{CO}_{2}$ emissions could be somehow (miraculously) achieved, with such a sudden increase in the volume of air-transport tourist trips, $\mathrm{CO}_{2}$ emissions of air transport would be higher by $50 \%$ in 2040 (than in 2005).

Since the main drivers of such a huge $\mathrm{CO}_{2}$ emissions rise are the growth of population income and sudden growth of low-cost companies, it is obvious that current climate policy for air passenger transportation is insufficient to achieve significant emission reductions if air transport's volume growth is not radically curbed. For this reason, current climate air transport policy focus should shift to more rigorous and efficient implementation of market-driven instruments, which, apart from creating incentives to develop and use low-emission technologies, can also reduce the demand for travel. 


\section{Acknowledgments}

This paper contains the research results of project No. 37010 funded and supported by the Ministry of Science and Technological Development of the Republic of Serbia.

\section{References}

1. IPCC. Climate change 2007: Synthesis report. Cambridge, UK: Cambridge University Press. 2007.

2. SCOTT D., PEETERS P., GÖSSLING S. Can tourism deliver its 'aspirational' emission reduction targets? Journal of Sustainable Tourism. 18 (3), 393, 2010.

3. JOVANOVIĆ M. Tourism and environmental protection. Megatrend Review. 8 (2), 371, 2011.

4. Airbus. Global Market Forecast 2015-2034. http://www. airbus.com/company/market/forecast/ (accessed: 03. October 2015)

5. GÖSSLING S., CERON J.P., DUBOIS G., HALL M. Hypermobile Travellers. In: Climate Change and Aviation. GÖSSLING S., UPHAM P. (Eds.). Earthscan: London. 2009.

6. UNWTO-UNEP. Climate change and tourism: Responding to global challenges. UNWTO: Madrid. 2008.

7. DUBOIS G., PEETERS P., CERON J. P., GÖSSLING S. The future tourism mobility of the world population: Emission growth versus climate policy. Transportation Research Part A. 45, 1031, 2011.

8. GOSSLING S., UPHMAN P. (Eds.). Climate Change and Aviation. Earthscan: London, 2009.

9. PEETERS P.M., WILliAMS V. Calculating Emissions and Radiative Forcing. In: Climate Change and Aviation. GOSSLING S., UPHMAN P. (Eds.). Earthscan: London, 2009.

10. CAO. ICAO environmental report 2013 - Aviation and climate change. ICAO, 2013.

11. National Academy of Sciences. Limiting the Magnitude of Climate Change. NAP: Washington DC, 2010.

12. SCHAFER A., VICTOR D. G. Global passenger travel: implications for carbon dioxide emissions. Energy. 24, 657, 1999.

13. PEETERS P. M., MIDDEL J., HOOLHORST A. Fuel efficiency of commercial aircraft - An overview of historical and future trends. National Aerospace Laboratory NLR: Amsterdam, 2005.

14. LEE D. S., FAHEY D. W., FORSTER P. M., NEWTON P. J., WIT R. C. N., LIM L. L., OWEN B., SAUSEN R. Aviation and global climate change in the 21 st century. Atmospheric Environment. 43, 3520, 2009.

15. UPHAM P., TOMEI J., BOUCHER P. Biofuels, aviation and sustainability. In: Climate change and aviation: Issues, challenges and solutions. GOSSLING S., UPHAM P. (Eds.). Earthscan: London, 2009.

16. HILEMAN J. I., ORTIZ D. S., BARTIS J. T., MIN WONG H., DONOHOO P. E., WEISS, M. A., WAITZ I. A. Near-term feasibility of alternative jet fuels. Santa Monica, CA: RAND Massachusetts Institute of Technology. 2009

17. MASCARELLI A. L. Gold rush for algae. Nature. 461, 460, 2009.

18. NYGREN E., ALEKLETT K., HÖÖK M. Aviation fuel and future oil production scenarios. Energy Policy. 37 (10), 4003, 2009.

19. UNEP. Towards sustainable production and use of resources: Assessing biofuels. Paris. 2009.
20. ÅKERMAN J. Sustainable air transport - on track in 2050. Transportation Research Part D, 10 (2), 111, 2005.

21. European Low Fares Airline Association. http://www.elfaa. com/statistics.htm (accessed: February 2016)

22. UNWTO. Compendium of Tourism Statistics. UNWTO: Madrid, 2014.

23. World Bank.http://go.worldbank.org/K2CKM78CC0 (accessed: December 2015)

24. Eurostat. http://ec.europa.eu/eurostat/data/database (accessed: December 2015)

25. SEETARAM N., FORSYTH P., DWYER L. Measuring price elasticities of demand for outbound tourism using competitiveness indices. Annals of Tourism Research. 56, $65,2016$.

26. JOVANOVIĆ M. Kuznets curve and urban transport the scope of I+M programs. Glasnik srpskog geografskog društva (Bulletin of the Serbian Geographical Society). 92 (4), 127, 2012.

27. DALEY B. Air Transport and the Environment. Ashgate, 2010.

28. RAUX C. The potential for $\mathrm{CO}_{2}$ emissions trading in transport: the case of personal vehicles and freight. Energy efficiency. 3 (2), 133, 2010.

29. JOVANOVIĆ M. Belgrade's Urban Transport $\mathrm{CO}_{2}$ Emissions from an International Perspective. Polish Journal of Environmental Studies. 25, 2, 2016.

30. JOUMARD R. The stakes of air pollution in the transport sector, from the French case. Atmospheric Environment. 39, 2491, 2005.

31. FRIMAN M., LARHULT L., GÄRLING T. An analysis of soft transport policy measures implemented in Sweden to reduce private car use. Transportation. 40 (1), 109, 2012.

32. OECD., UNEP. Sustainable Tourism Development and Climate Change: Issues and policies. Organization of Economic Cooperation and Development: Paris. 2011.

33. BANISTER D., HICKMAN R. Transport futures: thinking the unthinkable. Transport Policy. 29, 283, 2013.

34. GÖSSLING S., COHEN S. Why sustainable transport policies will fail: EU climate policy in thelight of taboos. Journal of Transport Geography. 39, 197, 2014.

35. European Commission. EU Transport in Figures. Statistical Pocketbook 2012. http://ec.europa.eu/transport/factsfundings/statistics/doc/2012/pocketbook2012.pdf.

36. IATA. A Global Approach to Reducing Aviation Emissions 2009. http:// www.iata.org/whatwedo/environment/Pages/ index.aspx

37. United Nations. http://esa.un.org/unpd/wpp/Download/ Standard/Population (accessed: January 2016)

38. PRESTON H., LEE S.D., HOOPER D.P. The inclusion of the aviation sector within the European Union's Emissions Trading Scheme: What are the prospects for a more sustainable aviation industry? Environmental Development. 2, 48, 2012.

39. JOVANOVIĆ M., VRAČAREVIĆ, B. The challenges of the tradable-permits use in transport sector. Collection of Papers - Faculty of Geography at the University of Belgrade. 61, 59, 2013.

40. ZETTERBERG L. How to integrate international aviation and shipping into a global emissions trading system. In: Beyond Bali, Strategic Issues for the Post-2012 Climate Change Regime. EGENHOFER C. (Ed.). Centre for European Policy Studies: Brussels, 2008.

41. ARES E. EU ETS and Aviation, Standard Note SN.SC/5533. House of Commons Library: London. 2012.

42. PENTELOW L., SCOTT D. Aviation's inclusion in international climate policy regimes: implications for 
the Caribbean tourism industry. Journal of Air Transport Management. 17, 199, 2011.

43. JOTZO F. Comparing the Copenhagen Emissions Targets. CCEP Working Paper. Canberra: Centre for Climate Economics \& Policy, Crawford School of Economics and Government, The Australian National University, 2010.
44. MAYOR K., TOL R. S. J. Aviation and the environment in the context of the EU-US Open Skies agreement. Journal of Air Transport Management. 15, 90, 2009.

45. European Commission. Reducing Emissions from Aviation. http://ec.europa.eu/clima/policies/transport/aviation/index en.htm (accessed: 15. September 2015) 